\title{
THE IDENTIFICATION OF RELIGIOUS GENOCIDE WITH EMPHASIS ON GENOCIDE OF SHIITES
}

\section{Mohammad Jamadi ${ }^{1}$}

\begin{abstract}
According to the International Criminal Law and the International Criminal Court, religious genocide is considered as a type of Genocide and the most significant similarity between them is that Religious Genocide is defined as the forced annihilation of religious groups. Because unlike the other instances of genocide, Religious Genocide does not have an official definition in international assemblies, one cannot make a proper judicial distinction between genocide and Religious Genocide. The primary motive behind most of the modern Religious Genocides has been formation of a unified religious-tribal mixture while in the middle ages and during the early modern era, the motive was generally based on mere religion. Results of the present study have shown that according to the article 6 of the statute of the international criminal court, religious genocide is formally identified as a variant of genocide; however there is no clear definition for this villainy. On the other hand, according to the Convention on the Prohibition of Genocide and the statute of the International Criminal Court, crimes against Muslims, especially the Muslims of Myanmar and the Shiites of Yemen and Bahrain are regarded to as explicit instances of Religious Genocide. It is worthy of mentioning that the present study is a descriptive analytical study.
\end{abstract}

Keywords: Genocide, Religious Genocide, Muslims, Shiites, The International Criminal Court.

\section{INTRODUCTION}

Religious genocide a newly coined word that refers to some sort of religious harassment through which a

\footnotetext{
${ }^{1}$ Ph.D Student of General International Law, Isfahan Branch, Islamic Azad University, Isfahan, Iran. E-mail: Dcm2000.co@hotmail.com
} 
religious uniformity is established in an area controlled by a religious majority through instruments such as detention, exiling and or even killing. Religious genocide is usually characterized by annihilation of a large portion of historical artifacts, graveyards, houses and other instances of religious civilization. It may be true that religious genocide is a variant of genocide which is mainly intended for annihilation of religious minorities in certain geographical areas and usually results in the modification of the religious geography of the area. Some believe that religious genocides have historical roots. Among the instances of religious genocide, it can be referred to the banishment of Jews from Spain in the $15^{\text {th }}$ century and annihilation of local American Indians by European immigrants and white colonialists. During the past few years, numerous villainies have taken place against Muslims, especially the Muslims of Rohingya in Myanmar and Shiites of Yemen. The facts indicate that during the past few years, the Muslims of Rohingya have been constantly exposed to discriminatory policies and cruel aggressions; this has eventually led to the wiping of them from their ancestral homeland. In addition, reports show that the Shiites too, especially the Shiites of Yemen are in unpleasant conditions. The basic question that rises in this context is that if these instances can be considered as religious genocide, and to what extent have the villainies against the Muslims of Rohingya and Yemen been consistent with the characteristics of genocide?

The probable answer to this question is that religious genocide is a variant of genocide and the villainies against the Muslims, especially the Muslims of Rohingya and the Shiites of Yemen are consistent with the described characteristics of genocide. In this regard, the present study firstly investigates the concepts of genocide and religious genocide and then, it investigates the consistency between these villainies and the regulations related to genocide; ultimately a final conclusion is made.

\section{IDENTIFYING RELIGIOUS GENOCIDE}

In this part of the article I try to investigate whether religious genocide has been supported in International Criminal Law and the statute of the international criminal court or not. To this end, i firstly determine and analyze the concept of genocide and afterwards, I will elaborate on religious genocide.

\section{DETERMINING THE CONCEPT OF GENOCIDE}

Genocide is one of the most important and extreme villainies against humanity; in fact nowadays among the other international crimes, genocide is known as the crime of crimes. On this basis, in the case of Rwanda, the international criminal court referred to the crime as the crime of crimes. By being placed among the crimes against humanity, genocide has been investigated in the verdicts of certain cases according to the rule 10 of the control 
council, the very first of which is the issue of justice. In this verdict, genocide was described as a primary image of a crime against humanity. Genocide includes deliberate killing, annihilation or intentional orientation of groups towards annihilation. Genocide was primarily evaluated as merely a subset of crime against humanity.

The very first legal definition of genocide was appeared in the statement of the UN in 1948 regarding prevention and punishment of the genocide crime. Approval of the international treaty of prevention and punishment of genocide was done on the December of 1948 by the general assembly of the UN with a majority of countries around the globe joining the treaty. This treaty resulted in wide condemnation of this villainy throughout the international community. The article 2 of the treaty which has been explicitly borrowed by the counts 2 and 4 of the statutes of the International criminal courts of Yugoslavia and Rwanda and, the article 6 of the statute of the International Criminal Court. These counts define genocide as follows: by genocide it is referred to one or some of the following described actions intended for the annihilation of the whole or part of a national, tribal, racial or religious group:

1. Murdering of the members of a group

2. Imposing extensive damage on the mental and physical health of members of a group

3. Deliberate putting of a group in unsuitable living conditions that lead to physical deterioration of the whole or part of that group

4. Taking actions preventing birth in a group

5. Forced transferring of the children from one group to another

Certain objections can be made to this definition. In the article 16 of the statute, there is no mentioning of political and social groups, while these groups too can be exposed to the mentioned villainy. Governments may take advantage of this gap. The determination of the moral factor of the crime, which is the special intention for annihilation of a certain group, is accompanied by special difficulties. In addition, the phrase of a part of the group is also ambiguous and it does not specify the number of individuals that are referred to as a part of the group. It seems that in the presence of the moral factor, even killing one member of a group is an instance of genocide crime.

It is unclear whether the points mentioned in the article 6 of the statute are limitative or figurative. However it seems that with respect to the principles of "narrow interpretation in criminal issues" and "legality of crimes and punishments", the mentioned counts have a limitative aspect.

After the Second World War, on the $9^{\text {th }}$ of December of 1948, the UN approved the convention on prevention and suppression of genocide. This crime has also been mentioned in the statute of the international criminal court. I will try to firstly define it and then I will try to investigate the effective factors in its realization as well as its instances. The article 6 of the statute of the international criminal court clarifies: by genocide it is referred 
to one of the following actions aimed at the annihilation of the whole or a part of a national, tribal, racial, and or religious group:

1. Murdering of the members of a group

2. Imposing extensive damage on the mental and physical health of members of a group

3. Deliberate putting of a group in unsuitable living conditions that lead to physical deterioration of the whole or part of that group

4. Taking actions preventing birth in a group

5. Forced transferring of the children from one group to another

Regarding comparison of crimes against Muslims and Shiites and, the regulations of genocide, I will investigate the conditions and regulations governing genocide in an expansive manner.

\section{RELIGIOUS GROUPS AS SUPPORT GROUPS}

The convention on prohibition and punishment of genocide and the statute of the international criminal court provide support for four national, racial, tribal and religious groups. In fact religious groups are one of the groups that are supported by the International criminal law against genocide. By a religious group it is referred to a group of people who share similar beliefs, habits and religious principles who worship the same being. There are several definitions for religion, and the point that all of them have in common is the immaterial and supernatural aspect of it. In general and by considering the entire humanity in all times, religion can be interpreted as the great orientation of humans towards the high place of God, with the aim of determination of the existential reasons beyond each human life. In the definition of religion we have: a religion is defined as an intertwined system comprised of beliefs, actions relating to holy artifacts that are considered especial and are not meant to be touched. These beliefs and actions unite the entire people who join them in a moral congregation named a church. In another popular definition proposed by Bole, the divine reality of religion is referred to explicitly. It holds: religion is defined as the set of beliefs and actions regarding an objective reality that is unique and collective but also high placed and somehow personal; to which the mankind finds him attached to and tends to keep the contact.

In this regard, Larose (20 th century) writes: occupation of mind by supernatural and divine affairs is one of the most universal and yet stable tendencies of the mankind. Hence the need for religion has adopted various shapes and forms throughout the history. Considering the fact that religion is the orientation of humans towards the god and creates a sort of personal and collective sense of communication with the higher realities, it can be concluded that religion has been mainly formed according to the circumstances of life and culture: agricultural groups in the Neolithic age believed in various forms of animism whereas ancient emperors created national gods. 
According to the mentioned content, a religious group can be considered as a set of people who have come together by a religion that is based on a holy and divine principle; this religion shows them as a whole and creates an inner sense of unity for each individual. However the concept of religious group does not include the entire complexities that exist in other groups and hence it can include any religious community that has bonds based on a unified religious ideal. In the view of the International Criminal Court in the case of Rwanda, a religious group is a group in which the members have similar/common beliefs and follow similar worship methods.

The large group of Armenians who were massacred on the $24^{\text {th }}$ of April of 1915 in Turkey is a clear instance of genocide against a religious group. The abstract criterion for assigning individuals to a special group suffices here; whether the violated person believes in his/her belonging to one of the aforementioned four-fold groups. On this basis, the court of former Yugoslavia in the case of Karadzic v. Ratka, while emphasizing on the precedence of the abstract criterion over the objective criterion believed that supposing any of the committers and victims belonged to a certain group in enough. Similarly, the court of Rwanda adopts the same perspective in the case of Jelisik and states:

$\ldots$ and or a group that considers itself as such, or a group that by others including the committers is viewed as such ...

\section{COMPARISON OF THE REgULATIONS OF GENOCIDE WITH THE CONDITIONS OF MUSLIMS AND SHIITES}

As mentioned earlier, any action towards the annihilation and or physical termination of the whole or a part of a racial, tribal, national, religious and or ideological group is considered as genocide. It should also be pointed out that forbidden actions regarding special groups must contain the characteristics stressed out in the context of genocide in order to be able to refer to them as genocide.

Following the bloody disasters of the Second World War, the general Assembly of the UN approved the Convention on the Prohibition and Punishment of Genocide on December $9^{\text {th }}$ of 1948 through the A260 Resolution. Not only the articles 2 and 3 of the Convention define this villainy and its related crimes, but also the article 6 talks about prosecution of the defendants in the courts of the crime scene country or in the International Criminal Court. The definition provided in the article 2 of the former convention has been perfectly adapted by the article 4 of the statute of the international criminal court of the former Yugoslavia, the article 2 of the statute of the international criminal court of Rwanda and the article 6 of the statute of the international criminal court of Rome. Crimes related to genocide including collusion, direct and explicit stimulation and, commencing and associating in genocide are referred to in the article 3 of the former convention, the $S 3$ of the article 4 of the statute 
of the Former Yugoslavia's international criminal court, the S3 of the article 2 of the Rwanda's International Criminal Court and, the article 25 of the statute of Rome's International Criminal Court. The identical definition that can be observed in these statutes is as follows: by genocide, it is referred to any of the following actions with the aim of annihilation of the whole or a part of a national, tribal, racial, or religious group:

1. Murdering of the members of a group

2. Imposing extensive damage on the mental and physical health of members of a group

3. Deliberate putting of a group in unsuitable living conditions that lead to physical deterioration of the whole or part of that group

4. Taking actions preventing birth in a group

5. Forced transferring of the children from one group to another

According to the mentioned documents, the instances of genocide have been mentioned in five separate clauses. Considering the preliminary actions of the convention on the prohibition and punishment of the crime of genocide (CPPCG) and the description of the convention provided by the international law commission and, the verdicts of the international criminal courts of former Yugoslavia and Rwanda it can be concluded that the formerly mentioned five-fold clauses have a limitative aspect. The International criminal court has adopted this approach as well and as it was previously mentioned, genocide is not a concept bound to a specific crime; rather it includes a set of criminal actions that take place extensively and with the aim of annihilation of the whole or a part of target groups.

The mentioned instances show that there exist two types of genocide namely as physical and biological and because of the oppositions of countries such as the former Soviet Union; it didn't come to include cultural and political genocide. In the case of Kambanda (the prime minister of Rwanda), the court identified him as a committee of the crime of genocide since he had not fulfilled his duty of stopping the massacres when he was well aware.

\section{MURDERING OF THE MEMBERS OF A GROUP}

Murders, in which the victim is a group of people, are considered as the most extreme instances of genocide. The right to live is a main pillar of law. In the view of the preliminary commission, instead of the word "Killing" one can use the phrase "causing death". In this regard deliberate nonfeasance which is generally intended for the annihilation of a group is also covered by the definition (article 6).

Regarding the number of victims of the crime it has been mentioned by the article 5 of the statute that in order to categorize a crime as genocide, the main aim must have been the annihilation of members of a certain 
national, tribal, racial, or religious group. If one person is killed as a part of a larger plan aimed at the annihilation of the whole or a part of a certain group, the accusation of genocide will not be disregarded. On this basis, for genocide to happen it is enough that the committer kills even one or a few people or causes their deaths (article 6). On this basis, the important issue is the plan for annihilation of the whole or a part of a certain group, not the number of victims; although it could be hard to prove the existence of such plans when there are a few victims.

Regarding the murder of the whole or a part of a group it should be said that one instance can be the Muslims of Rohingya. On the October of the present year, the UN Office for the Coordination of Humanitarian Affairs issued a statement and announced that with the alibi of confronting the armed militias, the army of Myanmar targeted many civilians. The statement also says: the number of people who have fled the Rakhin State and made it to Bangladesh since the beginning of violence in Myanmar on the $25^{\text {th }}$ of August has topped 519 thousand people. At least 3000 civilians have been massacred and a 1000 more are still trying to survive.

Regarding the genocide of the Shiites it should be said that by declaring war against Yemen, Arabia is trying to massacre the innocent civilians of this country, especially those who live in Shiite inhabited areas and this is an explicit instance of genocide. Jimmy Mc. Godlike the Coordinator of the humanitarian affairs of the UN in Yemen stated on the August of 2016 that there are no precise stats regarding the killed people in Yemen. He also said that while it is estimated that from the March of 2015 on, more than 6 thousand people have been killed in this country, the stats indicate the deaths of more than 10 thousand people. On the February of 2017, the legal center for law and development headquartered in Sana the capital of Yemen, stated through a report under the title of "consequences of 700 days of war" that during the 700 days of Arabia's attack on Yemen, 120411 people including 7063 men, 1870 women and 2568 children have been killed.

\section{IMPOSING EXTENSIVE DAMAGE ON THE MENTAL AND PHYSICAL HEALTH OF MEMBERS OF A GROUP}

Though there is no definition for this type of harm in the Genocide convention and the statute of the International criminal court, the judicial procedure believes that any action causing a modification in the body limbs and or any action that interferes with the senses of a person; such as torturing, inhumane and aggressive behaviors, and raping that explicitly harm the physics of a person are considered as instances of physical harm; and any attempt to create an interference in the mental state of the victim is the explicit instance of mental harm.

The occurrence of intense mental damage can be regarded to independent from physical harm. Forcing a victim to lie on the ground and threatening to cross over him/her with a vehicle, forcing a victim to assault another victim, and tying two victims together to choke them are considered as some actions that cause intense 
physical and mental damages.

The effects of deep harms such as continued raping will always remain in the psyches of the victims and cause them fear, anxiety and eternal terror. There are several support forums that tend to the survivors of such phenomena and their existence provides the survivors of massacres and rapes with a valuable opportunity to talk about their dark past, because everybody in these forums will be talking about similar experiences.

By taking a look at the actions of the Al-Khalifa in Bahrain we realize that this type of forbidden action has been occurring extensively with explicit instances. Using toxic tear gases that are responsible for the taking of lives of many children and elderlies, and the various instances of torturing are also happening worldwide in extensive forms. Tortures that torment both the psyche and physics of a human, such as dismantling limbs, flowing high voltage electricity through body and etc. are not only prohibited by the Convention on the prohibition and punishment of the crime of genocide, but also are banned by the universal declaration of human rights in its fifth article and the international civil and political covenant in its $7^{\text {th }}$ article.

Regarding Yemen, the three institutions of UNICEF, WFP (world food program), and WHO (world health organization) have given a warning that an ominous combination of war, malnutrition, and outbreak of Cholera has resulted in the immediate need of $80 \%$ of Yemeni children for humanitarian helps. After two days of investigation and negotiation regarding the disastrous condition of human lives in Yemen, the heads of the mentioned three institutes emphasized that more than two millions of these children are prone to Cholera because of malnutrition and that in most cases malnutrition and illnesses have been interacting with each other.

\section{DELIBERATE PUTTING OF A GROUP IN UNSUITABLE LIVING CONDITIONS}

Prevention of feeding, systematic destruction of residential sites, regular evictions, intense labor, lack of hygienic care and lack of medical care and pushing towards deserts and bad weathered areas are other types of gradual termination of a group. According to the 33 of the article 2 of the convention and the $s 3$ of the article 6 of the statute of the international criminal court genocide happens in the light of deliberate putting of a group in unsuitable living conditions. On this basis disregarding the fact that for genocide to happen it is necessary to somehow make the living conditions harsh for the victims seems irrational. Among the various instances of genocide it can be pointed to the section 2 of the indictment issued on the $24^{\text {th }}$ of the July of 1995 regarding the accusations and actions of Radwan Karadzic and Ratko Meladij by which the Muslims and Croatians of Bosnia were kept in unpleasant living conditions.

By investigating the living conditions of the Muslims of Rohingya in the country of Myanmar it becomes clear that they are deprived of their most basic citizenship and human rights. They are forced to work with no 
wage, they are not allowed to commerce, they cannot enter the army and also they are banned from presence in political scenes and or cultural and social institutions. They have to pay heavy taxes and are also banned from studying in the Universities of Burma. There are also cruel rules posited on the marriage of these people because of being Muslims.

Preventing the transfer of food to the Shiites of Yemen is a bold instance of genocide. Recently, George Kory, the chairman of the UN office of coordination of humanitarian affairs posted on his Twitter account and warned that barricading the border passages of Yemen will worsen the situation of this country. His post included: one of the saddest tragedies of the world is happening in Yemen. On the other hand, Yens Larke, the spokesman of the UN coordinating office of humanitarian rights has said: after short time after the barricading the border passages of Yemen, the normal life in this country has been affected significantly. He has also pointed to reports saying that fuel prices have increased up to $60 \%$, and that gas capsules' prices have increased up to $100 \%$. He also emphasized that the condition created by the barricading of the Yemen's border passages is truly worrying.

Approximately 27 million Yemeni people who are mostly Shiites are exposed to hunger and famine. 4.5 million Yemeni children have been deprived of education who will in case of continuation of the war either be absorbed as soldiers or will be the victims of underage unwanted marriages. The healthcare systems are at the threshold of collapse and the hospitals and care centers are significantly lacking medicine and equipment. The present food crisis, destruction of clinics and sewers systems, destruction of agricultural infrastructures and aiming for hygiene and transportation are being exploited by the Saudi led coalition as war tactics.

A series of secret detention centers in the southern areas of Yemen have been established by Emirates and its allies in which 100s of people have been detained, tortured, and disappeared.

According to the report of Relano, the representative of UNICEF in Yemen, currently 2.2 million Yemeni children are suffering from malnutrition and 460 thousands of them are already in severe malnutrition states.

Regarding the condition of the Shiites of Bahrain it should be said that destruction of hospitals, extensive arresting of hospitals' personnel with the alibi of curing the opponents of the sovereignty, extensive firing of people because having participated in demonstrations, harassing and terrifying the personnel of hospitals because of tending to the injured people, expulsion of students from universities and even institutes, cutting the funds of elite students and many other actions that are currently taking place can be considered as instances of putting the Shiites in harsh living conditions. Where there is no sense of security and there is in every moment a possibility for raid of police forces to homes, parents are afraid to send their kids to schools. Is not this worrying and harsh living condition an instance of unpleasant living conditions that is deliberately inflicted? When no one has social and job security because of their belief in a specific religion, how can one say that the conditions are normal? On this basis 
it seems that the situation Yemen is the explicit instance of deliberate putting of a group in unpleasant living conditions. Unpleasant living conditions are not only those inflicted on the Native Indians of US by the US government, rather the pleasantness of conditions of life must be evaluated with respect to the conditions and levels of welfare that are averagely expected in every era and area. When a nation is not able to use its potentials and talents because it believes in a specific religion or is from a specific tribe or race, there seems to be an unpleasant condition for life filled with hopelessness which gradually results in depression and other mental weaknesses that are ultimately followed by certain physical illnesses.

\section{TAKING ACTIONS PREVENTING BIRTH IN A GROUP}

Another instance of genocide is to prevent birth giving in a specific group through inhumane methods such as abortion, separation of men and women, prevention of marriage, sterilizing and genital mutilation. In the s7 of the article 7 of the statute of the international criminal court, raping, forced sterilization and alike are not considered as crimes against humanity, but this silence will not change the fact that if any of these actions is done with the aim of annihilation of the whole or a part of a group, it is considered as genocide. The international criminal court of Rwanda adopts the same view and states: prevention of giving birth that makes a person unable to reproduce and puts a threat on the other members of a group in a way that they also refuse to have children, is an instance of genocide.

\section{FORCED TRANSFERRING OF THE CHILDREN FROM ONE GROUP TO ANOTHER}

The most desirable time for cultural impact is childhood. According to this fact, the criminals of the crimes of genocide steal children and transfer them to other groups and use them for propagation of the hosting cultures with the aim of gradual deterioration of the pillars of a group internally. In this context, once again the intention of the committers is stressed out; if the children have been stolen for the mentioned purpose, it is considered as genocide; otherwise if they have been stolen for other things such as sexual misuse; it is considered as human trafficking. In addition the forced transferring of underage children with any intention is not included as genocide, and rather it will be investigated as crime against humanity.

The contemporary history shows that the Muslims of Rohingya have been moved towards the Northern Rakhin state where there are limiting policies inflicted on them. Trafficking in these areas is strictly controlled and limited and the daily chores and routine lives of people are controlled by the security guards. These actions have 
directly aimed for the prevention of birth giving and reproduction of the people of Rohingya. Strict population control and setting limits on marriage are consistent with the fourth clause, regarding the taking of actions that prevent birth giving in a group. In addition, ever since the violence started in 2012, approximately 140 thousand Rohingyan people are being kept in closed camps intended for the internally displaced Persons (IDP). The people who live in these camps are under strict limitations that are not imposed on the people who live in other areas of the Rakhin state. During the violence in 2012, a set comprised of government authorities, popular masses, and local masses approved the massacre of the people of Rohingya and hence had part in the annihilation of them. Many of the evidence gathered by human rights organziations indicate that during the violence in 2012, the government and its security forces had an axial role in the physical annihilation of the people of Rohingya along with their properties and communities. Despite the fact that the government was co-respondent in the annihilation of the people of Rohingya, the role of the security forces in the violence, in addition to institutionalization of discrimination and rape and assault against the people of Rohingya shows that the killings, violence and the assaults were aimed at the annihilation of the people of Rohingya. The fact that the security forces not only participated in the violence, but also encouraged this situation indicates that the government deliberately created a situation for the people of Rohingya that ultimately led to their annihilation. Increase in the amount of evidence pointing to the aggression against the people of Rohingya shows that forced transfer of Muslims, exiling them from Myanmar and approval of certain instructions and regulations for the people of Rohingya help with the annihilation of people of Rohingya. Hence the intention of the government is not only to exile the people of Rohingya from the state of Rakhin, but also the government is trying to create a condition that leads to the physical annihilation of the group.

\section{THE MENTAL ELEMENT OF GENOCIDE}

The majority of deliberate crimes require ill-will to take place. It means that the committee must be aware of his/her intention by undertaking a forbidden action. Some lawyers believe that in international organized crimes, the court does not need to investigate the mental aspect of the crime to approve ill-will, since it is presupposed.

This does not mean that these crimes are not supposed to have a mental aspect; rather there is no need to prove it since it is already assumed that it exists. The intentions of the committers are usually ineffective on the realization of the crime, however it sometimes causes discount on punishment in some cases. However, because of their special nature, crimes such as genocide are different and are mostly occurred based on specific intentions. In this regard the thin boundary between these crimes and other crimes, especially crimes against humanity is 
clarified. On this basis, in genocide the actions mentioned by the five-fold clauses must be done with specific intentions to annihilate the whole or a part of a tribal, national, racial, or religious group. A specific intention for the annihilation of the whole or a part of a group without occurrence of any criminal acts and without the conditions governing the event is not considered as genocide. The realization of genocide is bound to the intention of the committee for murdering the members of a group, imposing extreme mental and physical harms to a group, deliberate putting of a group in unpleasant living conditions, taking actions preventing birth giving and reproduction in a group, and forced transfer of children from one group to another. In the article 2 of the CPPGC and the article 4 of the statute of the former Yugoslavia's international criminal court, and the article 2 of the Rwanda's International criminal court's statute, and the article 6 of the statute of the international criminal court point to this issue. An action is considered genocide only when there as intention for annihilation behind it. On this basis the mental element of genocide is as follows:

1- General ill-will which is followed by the awareness of the conscious will of the committee about the action

2- Specific ill-will that is occurred under the light of the committee's intention for taking the life of the victim

3- Motivation, based on the want of the committee for the annihilation of the whole or a part of a specific group

In spite of the fact that nonfeasance can be another difference between normal murder and genocide in the view of Iranian Law, considering the repeated mentioning of the word "doing" in the article 290 of the Islamic Penal Code, the judicial procedure is not able to declare that nonfeasance can become the materialistic element of murder, hence the international judicial procedure makes no distinction between action and nonfeasance in the realization of genocide. In the third part of the indictment issued against Karadzic and Meladij on the $24^{\text {th }}$ of the July of 1995 it has been clarified that they were aware that their subordinates were about to kill and or impose extreme physical harms to the Muslims and Croatians of Bosnia but did nothing in order to wipe out the whole or a part of them as a specific group. Hence the court finds them guilty.

One of the complexities of the crime of genocide is to approve the will for annihilation of the group. If not impossible, it is indeed truly hard and difficult to do so and this has helped the criminals to get themselves free from these accusations by relying on the leverage of oversimplification. As in instance, the international criminal court accepted the Serbia's government denial of attempting genocide between 1991 and 1995 against nonSerbian groups. The court inferred that the main goal of the Serbia's government was trying to form the independent country of Serbia and announced that the evidence provided by the Bosnia's government cannot prove the occurrence of genocide. Despite the undeniable difficulty of determining the defendants' will by attempting any of the five-fold clauses, the international judicial procedure tries to explore the situation 
considering the conditions of each case. In this regard, both the international criminal courts of Rwanda and former Yugoslavia have considered the criterions of existence of will as continued killing, existence of specific plans, using humiliating expressions, quality of undertaken actions, number of victims of the group, the credibility and position of the victims, type of used weapons, and systematic purposefulness of victimizing the members of a group. In the tragedy of Rwanda, the number of victims of the Tootsie group has been estimated to be more than 800 thousand people. Belonging of the victims to a specific group, expansive and explicit propagations of the governmental groups and stimulation of the people of Hutu for killing the members of the Tootsie group in a way that 40-60 percent of men of the country took part in this tragedy are instances of genocidal wills.

\section{CONCLUSIONS}

In addition to the large number of killings, one hundred days of savagery of the criminals, existence of a organized political plan for stimulation of people towards killing the members of the Tootsie group are some other signs that were not ineffective in approval of genocide in the Rwanda case. The court's reliance on the conditions of each case means that the court must view the causes of each sign and disregard their subjectivity. Even killing one person who has a strategic position in a group and his/her absence will endanger the safety of the group can be genocide while killing a large number of people without any intent for annihilation of the whole or a part of a group is not considered as genocide. Hence it is crucial for the court to investigate and analyze the conditions of every case in a way that the final verdict is announced merely relying on the perceived signs and indicators. Regarding the manner of overcoming the difficulty of identification of the will of the committers, the solution is to distinguish between the two conditions in future reviews of the court. in this regard, the whole burden of proving the guilt is transferred from the court to the defendants. Like the aggression of extremist Serbians against the Muslims of Bosnia by killing 250 thousand citizens and raping more than 20 thousand women and torturing tens of thousands of people that hurt the intertwined feelings of the human community. Whether the case has a plenty of victims, or only one victim, the burden of proving the occurrence of genocide is on the shoulders of the prosecutor, because the mere number of victims cannot prove that genocide has taken place, unless the motivation behind the act is clarified. According to the previous verdicts of courts, this point has been welcomed by most lawyers and has been able to fill the gap in related regulations. On this basis, for the purpose of solving the difficulty of clarification of motivation, the formerly mentioned considerations would be inevitably considered by the judges in the oncoming cases. Regarding the mental element of the genocide of Muslims of Myanmar it has to be said that this crime was deliberate and with the aim of annihilation and exiling of the Muslims. The Muslims of Rohingya are not considered among the 135 officially recognized national races of the Myanmar and hence are 
not able to have a main nationality. The strict condition considered by the nationality rule for having acquired nationality in fact deprives the Muslims of Rohingya of having a nationality and hence the nationality of the Muslims of Rohingya is denied. The Myanmar's government's explanation for excluding the Muslims from officially recognized racial and national groups is that the Muslims of Rohingya are not locals of Myanmar; they have immigrated to Myanmar from the neighboring country of Bangladesh.

\section{A IDENTIFICAÇÃO DO GENOCÍDIO RELIGIOSO COM ÊNFASE NO GENOCIDIO DOS XIITAS}

\section{Resumo}

De acordo com o Direito Penal Internacional e com o Tribunal Penal Internacional, o genocídio religioso é considerado como um tipo de genocídio e a semelhança mais significativa entre eles é que o genocídio religioso é definido como a aniquilação forçada de grupos religiosos. Como, ao contrário dos outros casos de genocídio, genocídio religioso não tem uma definição oficial em assembléias internacionais, não se pode fazer uma distinção adequada por parte das autoridades judiciais entre genocídio e genocídio religioso. O principal motivo por trás da maioria dos genocídios religiosos modernos tem sido a formação de uma mistura religiosa-tribal unificada enquanto na Idade Média e início da era moderna o motivo foi baseado em mera religião em geral. Os resultados do presente estudo mostraram que de acordo com o artigo $6^{\circ}$ do Estatuto do Tribunal Penal Internacional, o genocídio religioso é formalmente identificado como uma variante do genocídio; No entanto, não há uma definição clara para essa vilania. Por outro lado, de acordo com a Convenção sobre a Proibição do Genocídio e do Estatuto do Tribunal Penal Internacional, crimes contra os muçulmanos, especialmente os muçulmanos de Mianmar e os xiitas do Iêmen e Bahrein são considerados como explícito caso de genocídio religioso. Vale ressaltar que o presente estudo é um estudo analítico descritivo.

Palavras-chave: Genocídio, Genocídio Religioso, Muçulmanos, Xiitas, Tribunal Penal Internacional. 


\section{REFERENCES}

Affaire Akayesu, n ICTR-96-4-T, TPIR, sentence, Chambre de première instance I, 2 octobre 1998.

Affaire Rutaganda, n ICT-R-96-3, Jugement et sentence, Chambre de première instance I, 6 décembre 1999.

Affaire Ruzindana, n ICTR-95-1,TPIR, Jugement ; Verdict ; sentence, Chambre de première instance II,21 mai 1999.

Akram Arefi, Mohammad, Religious and Ethnic Basics of the Taliban, Journal of Political Science, 4,1998.

Anatolia news agency, UN warning about humanitarian situation in Yemen, 11.8.2017 http:// aa.com.tr/fa.

Ardebili, Mohammad Ali, Habibzadeh, Mohammad Jafar and Fakhr Banab Hossein, Genocide and the necessity of its criminalization in Iran's criminal law, Journal of Modares University of Humanities, 10,2004, p. 3.

Ardebili, Mohammad Ali, Massacre, Legal Magazine, 11,1988.

Azari, Hadi, Definition and Description of Genocide Crimes in the Light of Judicial Procedure of International Criminal Courts for Rwanda and Former Yugoslavia, Journal of Legal Research, 10,2006.

Azizi, Sattar and Haji, Mohammad, Interaction Between Genocidal Contradiction and Genocide Prohibition, International Law Magazine, 45,2007.

Baiz Zadeh, Ibrahim, Review of crimes of genocide and crimes against humanity in the Statute of the International Criminal Court, Journal of Legal Investigations, 22,1997.

Baiz Zadeh, Ibrahim, Review of Crimes of Genocide and Crimes against Humanity in the Statute of the International Criminal Court, Journal of Legal Investigations, 22,1988.

Convention on the Prevention and Punishment of the Crime of Genocide (1948). G.A. Res. 260 (III) A,U.N. Doc. A/RES/260(III). Available from: http://www.oas.org/dil/1948_Convention_on. 
Cosse, Antonio, International Society and Massacre, Translated by Mohammad Ali Ardebili, Journal of Legal Research, Shahid Beheshti University Law School, 10,2008.

Fakhr, Hossein, The concept of genocide in the light of the Rwanda International Court of Justice, Conference on the Globalization of Rights and Challenges, Tehran University Shahid Beheshti Publishing, 2009.

Fredaynez, Facts About the Severity of Human Status in Yemen, Oct. 25, 2017http://www.fardanews.com/en/news/737754.

Goli Zavareh, Gholamreza, A passage over the history and culture of the Muslim community of Myanmar, Journal of Lessons from the School of Islam, vol. 621,2012.

Human Rights Watch. "All you Can do is pray: Crimes againsthumanity and ethnic cleaning of Rohigya Muslims in Burma’s Arakan state” 2013. 165 p.Available from: http://www.hrw.org/sites/default/files/ reports/burma0413webwcover_0.pdf.

Ilna, about 3,000 Muslims have been slaughtered in Myanmar, 2013/06/13 http://www.ilna.ir.

Irish Centre for Human Rights. "Crimes against Humanity in Western Burma: The Situation of the Rohingyas", National University of Ireland, Galway, 2010, 153 p. Available from: http://burmaactionireland.org/images/ uploads/ICHR_Rohingya_Report_2010.pdf.

IRNA, UN: $80 \%$ of Yemeni children need urgent assistance, August 4, 2017. http://www.irna.ir/fa/News/82611242.

ISNA, UNICEF considered the situation of Yemeni children as catastrophic, May 2, 1396. https://www.isna.ir/news/96020200826.

Javad, International Criminal Tribunal, Forest Publishing, Tehran, 2009.

Khaleghi, Ali, Habibzadeh, Mohammad Jafar, The crimes committed in Abu Ghraib prison from the point of view of criminal justice ", Journal of Legal Justice, pp. 80,2011. 
Kriyantsak Kitschyasari, International Criminal Law, translation of Hossein Aghaei Janat Shahr, First Edition, Daneshjoo Publishing House, Tehran, 2003.

Leadership Council on Foreign Relations, The Legal Dimensions of Genocide in Yemen by Saudi Arabia, April 23, 1396. http://www.scfr.ir/fa.

Mir Mohammad Sadeghi, Hossein, An Investigation of Crimes Against Humanity in the former Yugoslavia with a Special View of Crimes Against Women, Judicial Publishing, Tehran, 2003, p. 101.

Najafi Obrandabadi, Ali Hossein, United Nations Criminal Policy, Journal of Legal Research, Shahid Beheshti University Law School, 2011, 18,134.

Outdoor, Allan, Social Sciences Culture, Translation by Bagher Saroukhani, Third Edition, Kayhan Publishing, Tehran, 1996.

Shariat Bagheri, Mohammad Javad, International Criminal Law, Ninth Edition, Immortal Forest, Tehran, 2008.

Sharifi, Mohsen, Corps of Genocide in the Light of International Judicial Documents and Procedure, Magazine of Excellence in Law, 15,137.

the_Prevention_and_Punishment_of_the_Crime_of_Genocide.pdf.

William A. Schabas, "An Introduction to the International Criminal Court", 3th ed, (New York: Cambridge University Press 2007.

Zarni, Maung; Cowley, Alice. “The Slow-Burning Genocide of Myanmar's Rohingya”. Pacific Rim Law \& Policy Journal, 23/3: 2014,682-752. Available from: http://www academia. edu/77871 41/Compil ation_ 2014_Pacific_ Rim__ Law_and_Policy_Journal_Association_THE_SLOWBURNING_GENOCIDE_OF_MYANMARS_ROHINGYA

Trabalho enviado em 06 de setembro de 2018 Aceito em 03 de novembro de 2018 